\title{
Estimating the Cost of Equity and Equity Risk-Premia of Canadian Firms
}

\author{
George Athanassakos \\ Wilfrid Laurier University, Canada
}

This article proposes an alternative approach to estimating the required rate of return on equity, combining the bond-plus risk-premium approach and the Capital Asset Pricing Model, and tests it using Canadian data. Individual stock risk-premia are classified into groups according to the point in the business cycle, risk based on each company's bond rating, and industry groups as defined by industry classification. Group averages are calculated. We find equity risk-premia are negatively related to interest rates and bond ratings. Moreover, the higher the risk of an industry group, the higher are the equity risk-premia. However, findings regarding the risk-premia's sensitivity to the business cycle and stability across business cycles are not very conclusive (JEL G31, G12).

Keywords: equity risk-premia, cost of equity, CAPM, bond-plus riskpremium.

\section{Introduction}

This article proposes an alternative approach to estimating the cost of equity (required rate of return on equity), combining the bond-plus riskpremium approach and the Capital Asset Pricing Model (CAPM), and tests it using Canadian data. The study covers the period 1980:1 to 1992:12. As relevant evidence from the Canadian markets is provided, and in light of the differences in the institutional setting between Canada and the U.S., this study will improve our knowledge across markets and provide some useful insights to Canadian and international

\footnotetext{
${ }^{*}$ The author would like to thank Bob Leshchyshen of Dominion Bond Rating Service of Toronto for providing the bond rating data and also acknowledge the excellent research assistance of John Bagnall, Madhav Hari, and Cory Dawe. The helpful comments of Marie Racine and the participants of the Joint Wilfrid Laurier University and University of Waterloo Finance Seminar Series are gratefully acknowledged.
}

(Multinational Finance Journal, 1997, vol. 1, no. 3, pp. 229-254)

(C) by Multinational Finance Society, a nonprofit corporation. All rights reserved. DOI: $10.17578 / 1-3-3$ 
investors. $^{1}$

The bond-plus risk-premium method derives the cost of equity by adding an expected risk-premium to the cost (expected return) of a company's own long-term debt (Weston and Copeland [1992, pp. 610611], and Brigham et al. [1985]). The cost of debt for a company is calculated using the YTM on its traded bond. In the absence of traded bond, the cost of debt for the company is approximated using the YTM on traded bonds of similarly-rated companies. Thus, the key to the bond-plus risk-premium approach is to estimate the expected riskpremium of a company's equity over its cost of debt. To this end, the article combines the CAPM and the bond-plus risk-premium method. We model the equity risk-premia as a function of the level of interest rates, industry classification, bond rating and point in the business cycle and develop hypotheses to test the rigors of the equity risk-premia estimated in the article against expectations suggested by prior theory.

Although this approach can be applied to the estimation of the cost of equity of any company, it is particularly useful for the valuation of private companies and business units of multi-business corporations which, although they have rated bonds outstanding, have no publicly-traded stock. Moreover, this approach is very useful in estimating the cost of equity of small stocks which, in Canada, have been found to be "notoriously thinly-traded" (Fowler et al. [1980]). Finally, the bond-plus risk-premium approach as developed in this article, due to its simplicity and ease of application, can be particularly helpful to practitioners. ${ }^{2}$

The rest of the article is organized as follows. Section II reviews the literature. Section III discusses the bond-plus risk-premium approach and develops testable hypotheses based on suggestions of prior theory.

1. There are substantial differences between Canada and the U.S., despite their proximity and interdependence of their economies. Canada has a resource-based economy which has been adversely affected by the dis-inflationary environment of the 1980's. What has also weighed heavily on the Canadian markets are the unprecedented levels of federal deficit $(5 \%)$ and net federal debt $(72.8 \%)$ as a percentage of GDP, which are among the highest in the industrialized world, and the political uncertainty introduced by the secessionist tendencies in parts of Canada, most notably in the Province of Quebec. Finally, the government has played a much larger role in the Canadian economy than the U.S., attempting to manage the economy with constant tax increases and wealth redistribution policies.

2. Cornell, Hirshleifer, and James (1997) state that there is "a strong bias in favor of simple models that can be easily understood and adjusted" in the practitioners' circles and aversion to models that are "so complex that (they) cannot be easily applied and intuitively amended" (p. 7). 
Section IV discusses the sample selection and data. Section V presents the methodology and empirical evidence, and Section VI the implications of this article and conclusions.

\section{Alternative Procedures in Estimating Equity Risk-Premia}

In estimating the required rate of return on equity, $K_{s}$, analysts have predominately used the CAPM. The risk-premium associated with the CAPM is the market risk-premium defined as $\left(K_{m}-R_{f}\right)$, where, $K_{m}$ is the return on the market portfolio and $R_{f}$ is the return on a risk-free security. However, the CAPM provides little practical advice on how to estimate the market risk-premium. As a result, most empirical research on the subject of risk-premia revolves around approaches to estimating the market risk-premium.

A number of researchers in the U.S. and Canada, such as Ibbotson Associates (1990) and Boyle et al. (1989), provide historical holding-period returns on stocks and bonds from which the market riskpremium can be calculated as the difference between the historic average annual returns on a value-weighted market portfolio of stocks and an index of long-term treasury bonds. The historical averages are calculated over an extended time period which covers recessions, recoveries, periods of high and low interest rates, and periods of fast and slow economic growth. The latter approach is based on the assumption that past realizations are a good proxy for future expectations and that risk-premia are constant over time.

Vandell and Kester (1983), Malkiel (1979), Harris (1986), Brigham et al. (1985), and Harris and Marston (1992), estimate risk-premia based on the Discounted Cash Flows (DCF) or Dividend Growth Model (DGM). Often these models are based on a consensus measure of financial analysts' forecasts of earnings as a proxy for investor expectations to calculate each company's growth rate rather than assuming that investors expect future returns to mirror past returns. In general, these authors use the dividend growth model in its single constant growth or multiple growth versions to estimate $K_{s}$ for each company in the Dow Jones Industrial and Utilities Indexes or in the S\&P 500 Index. Then all $K_{s}^{\prime}$ s are averaged and weighted by each company's market value weights to arrive at a forward-looking estimate of $K_{m}$. The equity risk-premium is then derived by subtracting the current yield-to-maturity on the long-term treasury bonds from $K_{m}$. 
These studies find that the expected equity risk-premia are not constant over time and that they vary with interest rates and proxies of risk, but not in a consistent manner.

In CAPM applications, the estimated risk-premium, whether historic (i.e., the Ibbotson Associates method) or projected (i.e., the DCF method), is then multiplied by a stock's beta and added to the current yield-to-maturity of a portfolio of long-term (i.e., 10 year or longer) treasury/government bonds to derive the stock's expected rate of return (Brealey and Myers [1988]).

This article adds to earlier empirical work in a number of important ways. First, an alternative approach to estimating the cost of equity capital is proposed and tested. It is particularly useful for estimating the cost of equity of private companies, thinly-traded companies, and business units of multi-business companies which have no publicly traded stock. While this alternative approach to estimating the cost of equity is consistent with the CAPM, it is more easily understood and applied by practitioners than the CAPM-based cost of equity. Second, the structure of the bond market has dramatically changed in recent years (Booth [1995]), and this article examines a more recent period visà-vis earlier studies. This article's time period also incorporates three recessions (two of them severe), periods of fast and slow growth, and periods of rising and falling interest rates and inflation.

Third, in addition to being more flexible and applicable than the CAPM-based cost of equity, the bond-plus risk-premium approach is subject to a smaller margin of error in applications because it uses the yield-to-maturity (YTM) to which the equity risk-premium is added. This makes the bond-plus risk-premium approach particularly helpful to practitioners. The YTM, being the expected return on the bond's market value, already incorporates an expected (ex-ante) premium by the markets. The bond yield is easily determined if the bond trades, or can be approximated by the YTM on similarly-rated companies, provided the company has already rated bonds outstanding. Finally, the article tests for the rigor (and stability) of the equity risk-premia using a number of different hypotheses which emerge from prior theory and which are related to interest rates, industry classification, bond rating, and point in the business cycle. ${ }^{3}$

3. The required rate of return reflects not only the risk of the individual stock and company characteristics, but also the industry in which the company belongs, as well as the level of interest rates and the point in the business cycle of the economy. That's why we employ a joint macro-economic, industry, and bond-rating classification analysis to capture 


\section{The Bond-Plus Risk-Premium Model and Testable Hypotheses}

\section{A. The Model}

The bond-plus risk-premium method derives the cost of equity (required rate of return on equity) by adding an expected risk-premium $(E R P)$ to the company's own cost of long-term debt. ${ }^{4}$ That is, if the company's debt holders demand YTM, the company's shareholders should demand

$$
K_{s}=Y T M+E R P
$$

This approach has intuitive appeal since the cost of equity should be greater than the cost of debt. The beta of long-term debt for a company, $\beta_{d}$, is typically less than the beta of its common stock, $\beta_{s}$. Thus, equity holders demand a premium over the return debt holders demand from the company (Fama and French [1989]). This method is consistent with the CAPM approach (Weston and Copeland [1992], p. 611). ${ }^{5}$ In fact, the CAPM can be viewed as a specific case of the bond-plus riskpremium approach examined in this article (Brigham et al. [1985]).

Both debt and equity can be evaluated using the CAPM, with debt having a lower beta than equity. If we substitute in the above equation for YTM and $K_{s}$ their equivalent using the CAPM, i.e.,

$$
\begin{gathered}
Y T M=R_{f}+\beta_{d}\left(K_{m}-R_{f}\right), \text { and } \\
K_{s}=R_{f}+\beta_{s}\left(K_{m}-R_{f}\right),
\end{gathered}
$$

we find that

$$
E R P=\left(\beta_{s}-\beta_{d}\right)\left(K_{m}-R_{f}\right) .
$$

However, obtaining the beta of debt is not as straightforward as

the economic, industry, and company- specific risks and characteristics.

4. The expected risk-premium applicable to the bond-plus risk-premium model refers to the difference in expected returns between a company's stock and its own long-term bonds. This risk-premium is different from the market risk-premium applicable to the CAPM, which refers to the difference in expected returns between the market portfolio and risk-free bonds.

5. Although the CAPM has been subject to criticism in recent years (see Fama and French [1992]), Pettengill et al. (1995) have found support for CAPM and the positive relationship between beta and expected returns. 
obtaining the beta of equity. Hence, equity risk-premia will be estimated via a different route, namely the bond-plus risk-premium approach proposed in this article. The article's methodology ensures the consistency between the bond-plus risk-premium approach and the CAPM. First, this article uses the CAPM to estimate specific company equity risk-premia. The specific company equity risk-premia are then aggregated by industry and/or rating. Finally, the aggregate risk-premia for the industry and/or rating class to which a company belongs are added to the company's own before-tax cost of debt to arrive at the bond-plus risk-premium-based cost of equity for the company.

\section{B. Testable Hypotheses}

Testable hypotheses are developed below that will be used to assess the reliability of the expected equity risk-premia estimated in the article.

\section{Bond Ratings}

Empirical studies provide evidence that (i) there is a relationship between the level of risk and bond rating of a firm, (ii) current bond ratings provide information about the relative risk of a company's securities, and (iii) rating agencies evaluate successfully the risks of new bond issues, e.g., Wakerman (1990). Also, using U.S. data, Fama and French (1989) find that as a firm's default risk increases, its equity risk-premium increases due to the junior position of equity claims relative to debt claims in bankruptcy. This leads to the following testable null hypothesis:

$$
\begin{aligned}
& \mathrm{H}_{0}{ }^{1} \text { : There is no relationship between the bond rating of a company } \\
& \text { and the expected equity risk-premium. }
\end{aligned}
$$

If the equity risk-premium is driven by a company's total risk (Lakonishok and Shapiro [1986]), we would expect a negative relationship between the premium that equity holders demand over the return on the company's debt and its bond rating. Hence, the above null hypothesis should be rejected.

\section{Industry Classifications}

The Toronto Stock Exchange (TSE) has an industrial classification system based on the line of products firms produce and the influence the business cycle has on this product. Although this classification system is not perfect, as it groups firms that in many cases are not very 
homogeneous, it will suffice for our analysis, as long as clear differences in risk characteristics exist between industries (Hatch and White [1988], p.195).

Industry groups differ widely in their risk characteristics as reported in Reilly and Drzycimski (1974). They find that there is a wide range of risk levels among different industries and that the risk measures over time were reasonably stable. Therefore, although risk measures for different industries show substantial dispersion during a period of time, individual industries' risk measures are stable over time. This means that the analysis of past industry risk is necessary, and that this historical analysis can aid attempts to estimate the future risk for an industry. This leads to the following testable null hypothesis:

$\mathrm{H}_{0}^{2}$ : There is no relationship between the industry classification ranking of a company and the expected equity risk-premium.

If the equity risk-premium is driven by a company's systematic risk, proxied by the company's industry classification ranking, then we should expect that the higher the riskiness of the particular industry classification, the higher the premium that equity holders will demand over the return on the company's own debt. Hence, the above hypothesis should be rejected.

\section{Business Conditions/Cycles and Interest Rates}

Nominal and real interest rates rise during economic expansions and fall during economic contractions. Yield spreads between bonds of varying risk often change in response to changes in economic activity. Bond investors become more quality-conscious during recessions. If investors are pessimistic about the economy, yield spreads widen, perhaps because investors worry that corporations are more likely to default on bonds during economic contractions. As a result, the investors require a higher reward for holding riskier securities. On the other hand, when investors are optimistic about the economy, yield spreads narrow.

Chan, Hamao, and Lakonishok (1991) and Fama and French (1992) find that expected stock returns are positively related to the ratio of book-to-market value of common equity and negatively related to size. These findings suggest that the above variables can be used as proxies for omitted risk factors. He and $\mathrm{Ng}$ (1992) test whether the temporal behavior of the average risk-premia associated with fundamental risk 
factors and the state variable proxies are driven by common economic forces. They show that the risks inherent in size and the book-to-market equity ratio correspond to the risks associated with the term premium and the default risk premium. That is, both variables are good proxies for business conditions. This leads to the following testable hypothesis:

$\mathrm{H}_{0}{ }^{3}$ : There is no difference in the expected equity risk-premium between recessions and recoveries.

If the equity risk-premium is driven by corporate profits, investors' mood about the economy, and their general perception of risk in the investment environment, and if these are proxied by the point in the business cycle, we should expect the premium that equity holders demand over the return on the company's own debt to be higher during recessions than during recoveries. Hence, the above hypothesis would be rejected.

\section{Sample Selection and Data}

\section{A. Sample Selection}

This article covers the period January 1980 to December 1992. The time period of this article is limited by the availability of company bond ratings. Our sample includes company data subject to the following criteria:

1. All companies have bonds rated by the Dominion Bond Rating Service.

2. All companies have stocks traded on major Canadian exchanges.

3. All companies have beta estimates in the TSE/Western data base.

4. All companies are classified under an industry in the Toronto Stock Exchange Index Review.

5. All companies have bonds rated between AAA and BBB so that their yields-to-maturity for the particular rating class can be obtained from ScotiaMcLeod.

The final sample contains 10,465 observations for 103 firms representing 13 out of 14 industries classified in the Toronto Stock Exchange Index Review. 


\section{B. Data}

Company bond ratings were obtained from the Dominion Bond Rating Service (DBRS) of Toronto, DBRS Historical Index Report. ${ }^{6}$ The sample characteristics are reported panels A and B of table 1. Panel A presents the distribution of the firms and observations in the sample by bond rating. For the purpose of this article, ratings are quantified by 1 if AAA to 4 if BBB. Panel B presents the distribution of the firms and observations in the sample by industry classification. The industry classifications were obtained from the Toronto Stock Exchange Index Review and cross-checked against the Report on Business Magazine, which also reports each company's general industry group. For the purpose of this article, industry groups are quantified by 1 if Mines \& Minerals to 14 if Conglomerates. Industries \#1 to \#7 have higher total risk than industries \#9 to \#14 (Hatch and White [1988, p. 195]). ${ }^{7}$

Some stocks appear in more than one rating class because their bond ratings were changed over the study period. All companies with the exception of two were traded on the TSE. The latter two companies were traded on the Alberta and the Montreal Stock Exchanges.

The bond yields for each rating class were obtained from ScotiaMcLeod's Handbook of Canadian Debt Market Indices, Section of Long-Term Bond Index. The only ratings for which YTMs were available were AAA, AA, A, and BBB. The YTMs for Canadian government bonds were also obtained from the same source. Individual bond yields were not available on most companies' bonds because of infrequent trading. As a result, we had to employ the average YTMs per rating class, obtained from ScotiaMcleod. For consistency, this approach was followed for all bonds in the sample.

Monthly beta statistics were obtained from the TSE/University of Western Ontario Data Base (TSE/Western). Finally, the timing of the recessions and recoveries were obtained from Statistics Canada. Over the period of our study (1980:1 to 1992:12), Statistics Canada has classified as recessions the periods 1980:1 to $1980: 6,1981: 8$ to 1982:12 and 1990:3 to 1991:3. For the purpose of this study, the points in the business cycle are quantified by 1 if recessions and 0 if recoveries.

6. Our sample encompasses all companies with a DBRS rating that are publicly traded in Canadian exchanges.

7. Industry \#8, Transportation \& Environment, is not represented in our sample, as DBRS rated no companies in that industry over the period covered by our article. 
TABLE 1. Sample Characteristics

\begin{tabular}{lcc}
$\begin{array}{l}\text { A. Risk Classification } \\
\text { Bond Rating }\end{array}$ & & \\
\hline AAA & 240 & 7 \\
AA & 2,401 & 33 \\
A & 5,653 & 84 \\
BBB & 2,171 & 49 \\
Total & 10,465 & 173 \\
\hline
\end{tabular}

B. Major Industry Classification ${ }^{\text {a }}$

\begin{tabular}{|c|c|c|c|c|c|c|}
\hline \multirow{2}{*}{$\begin{array}{l}\text { TSE Industry } \\
\text { Classification }\end{array}$} & \multirow{2}{*}{$\begin{array}{l}\text { Number of } \\
\text { Companies }\end{array}$} & \multirow{2}{*}{$\begin{array}{l}\text { Number of } \\
\text { Observations }\end{array}$} & \multicolumn{4}{|c|}{ Companies per Rating } \\
\hline & & & AAA & $\mathrm{AA}$ & A & $\mathrm{BBB}$ \\
\hline Metals \& Minerals & 4 & 528 & & & 3 & 3 \\
\hline Gold \& Precious Metals & 2 & 154 & & & 2 & 1 \\
\hline Oil \& Gas & 9 & 1,051 & 2 & 3 & 7 & 7 \\
\hline Paper \& Forest Products & 7 & 734 & & & 7 & 7 \\
\hline Consumer Products & 9 & 1,135 & & 5 & 8 & 1 \\
\hline Industrial Products & 20 & 1,782 & & & 23 & 13 \\
\hline Real Estate & 8 & 538 & & 3 & 6 & 4 \\
\hline Pipelines & 5 & 639 & & 2 & 5 & 2 \\
\hline Utilities & 11 & 1,063 & 1 & 4 & 8 & 4 \\
\hline Communications. \& Media & 4 & 264 & & 2 & 3 & 1 \\
\hline Merchandising & 4 & 516 & & 1 & 4 & 1 \\
\hline Financial Services & 16 & 1,641 & 4 & 10 & 9 & 2 \\
\hline Conglomerates & 4 & 420 & & 3 & & 2 \\
\hline Total & 103 & 10,465 & 7 & 33 & 84 & 49 \\
\hline
\end{tabular}

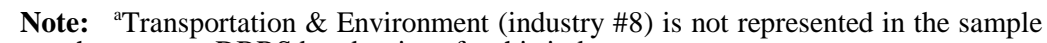
because there are no DBRS bond ratings for this industry.

\section{Methodology and Empirical Results}

\section{A. Construction of Equity Risk-Premia}

For each month and stock, an equity risk-premium is calculated by subtracting that month's $Y T M$ for the DBRS bond rating class to which a company's bonds belonged from the CAPM-based required rate of return on equity of the same company's own common stock. As indicated in footnote 5, Pettengill et al. (1995) have found support for CAPM and the positive relationship between beta and expected returns. 
They recognize that the positive relationship between beta and returns is based on expected rather than realized returns. When adjusting for the expectations concerning negative market excess returns, they find a consistent and significant relationship between beta and returns. Hence, it is reasonable to use the beta and CAPM to estimate the cost of equity for each stock in our sample. ${ }^{8}$

The CAPM-based required rate of return on a company's equity for a given month was estimated by adding the long-term (over 10 years) government of Canada bond YTM for the month to the product of the company's own beta for the month times a market risk-premium. The market risk premium is based on historical realizations of common stock and long-term government of Canada bond returns. ${ }^{9}$ As the historic market risk-premium has changed in recent years, as calculated in Brealey et al. (1986, p. 127) and Brealey et al. (1992, p. 143), from $8.0 \%$ to $6.7 \%$, respectively, the market risk-premium we used was $8.0 \%$ from 1980 to 1983 and $6.7 \%$ from 1984 to $1992 .{ }^{10}$ The year in which the market risk-premium was changed in the study corresponds to the timing of changes in the structure of the bond market in Canada, as discussed by Booth (1995). This effect led to the lower market riskpremium incorporated in common stock valuations in the latter part of the 1980s. The period of the change also corresponds with and captures the change in U.S. monetary policy in 1984 (Jaffee [1989, p.499]), to be discussed later, which had an impact on the Canadian capital markets. Finally, the choice of 1984 as the year of change in the risk-premium is consistent with Maddox et al. (1995, p. 92), who also recognize 1984 as a year of "major changes in the relative risks of debt and equity."

The equity risk-premia per month and per stock were classified into various groups cross-sectionally (by rating and industry classification)

8. The CAPM is used at this early stage of the methodology and not in the application of the bond-plus risk-premium method. The CAPM is used to estimate specific company equity risk-premia, which are subsequently aggregated. These aggregate risk premia are then used in the bond-plus risk premia method.

9. The beta coefficient is calculated in the TSE/Western data base using total monthly returns over sixty months. The beta estimate is updated on a monthly basis.

10. The market risk-premia have been calculated by Brealey et al. (1986, p. 127) and Brealey et al. (1992, p. 143) as the difference between the historical averages of the annual rates of return of Canadian common stocks and long-term government of Canada bonds over the periods 1926-1981 and 1926-1988, respectively. For their calculations, Brealey et al. (1986, 1992) use annual rates of return data on Canadian common stocks and long-term government bonds; found in Boyle et al. $(1984,1989)$. 
and over time (by the point in the business cycle). Average risk-premia were then calculated for each rating group, industry group, and point in the business cycle. Finally, a number of regressions, to be discussed in the next section, were also run involving all individual company equity risk-premia in the sample, interest rates and points in the business cycle.

\section{B. Summary Statistics of Equity Risk-Premia}

Summary statistics of the key variables employed in this article appear in table 2. In panel A, the average equity risk-premium for the 1980:1 to $1992: 12$ period is calculated to be $5.08 \%$. As expected, it is positive, which is consistent with equity holders demanding extra compensation over the compensation demanded by bond holders. This finding is also consistent with earlier studies. For example, Harris and Marston (1992) estimated the equity risk-premium based on the DCF/DGM method using U.S. data over a comparable period and found an average riskpremium of $5.13 \%$. Finally, as shown in panels B and C of table 2, the average equity risk-premia for sub-periods 1980:1 to 1983:12 and 1984:1 to $1992: 12$ are calculated to be $5.04 \%$ and $5.09 \%$, respectively, which are not significantly different from each other. ${ }^{11}$

To dissect the risk-premia further and test whether they change over time and/or across the year, we run two pooled-data dummy variable OLS regression models. The first model is designed to test if the mean risk-premia are statistically different from zero across the years 1980 to 1992, or by month of the year. This model is given by:

$$
R P_{i, t}=\sum_{j} a_{j} D_{i, t}^{j}+e_{i, t},
$$

where, $R P_{i, t}$ is the equity risk-premium per stock $i$ in year or month $t$, $D_{i, t}^{j}$ is a dummy variable that is equal to 1 if the current year or month is $j$ and 0 otherwise and $e_{i, t}$ is the error term assumed to be normally distributed with zero mean and finite variance. This is a restricted regression with the intercept suppressed. The $R^{2}$ and F-statistic from this model are not valid and hence not reported.

11. The 1980-1983 and 1984-1992 sub-periods were chosen because of earlier evidence that 1984 was the year a major change took place in market risk-premium. A different breakup of the overall sample period was also attempted, namely 1980-1985 and 1986-1992 with average risk-premia calculated to be $4.74 \%$ and $5.26 \%$, respectively, for the two sub-periods. These equity risk-premia are not materially different from those reported in the article. 
TABLE 2. Statistics of Key Variables

A. Period 1980:1 to $1992: 12$

\begin{tabular}{llllll} 
Variables & Mean & Median & Std & Min & Max \\
\hline RISK-FREE $^{\mathrm{a}}$ & .1093 & .1042 & .0183 & .0819 & .1766 \\
BOND YIELD $^{\mathrm{b}}$ & .1196 & .1135 & .0191 & .0887 & .1946 \\
RATING $^{\mathrm{c}}$ & $\mathrm{n} / \mathrm{a}$ & $\mathrm{n} / \mathrm{a}$ & $\mathrm{n} / \mathrm{a}$ & 1 & 4 \\
INDUSTRY $^{\mathrm{d}}$ & $\mathrm{n} / \mathrm{a}$ & $\mathrm{n} / \mathrm{a}$ & $\mathrm{n} / \mathrm{a}$ & 1 & 14 \\
BETA $^{\mathrm{e}}$ & .8783 & .8520 & .3415 & .1150 & 3.0570 \\
RISK-PREMIUM & .0508 & .0492 & .0229 & .0024 & .1924
\end{tabular}

B. Period 1980:1 to $1983: 12$

\begin{tabular}{llllll} 
Variables & Mean & Median & Std & Min & Max \\
\hline RISK-FREE $^{\mathrm{a}}$ & .1304 & .1296 & .0175 & .1118 & .1766 \\
BOND YIELD $^{\mathrm{b}}$ & .1457 & .1377 & .0195 & .1178 & .1946 \\
RATING $^{\mathrm{c}}$ & $\mathrm{n} / \mathrm{a}$ & $\mathrm{n} / \mathrm{a}$ & $\mathrm{n} / \mathrm{a}$ & 1 & 4 \\
INDUSTRY $^{\mathrm{d}}$ & $\mathrm{n} / \mathrm{a}$ & $\mathrm{n} / \mathrm{a}$ & $\mathrm{n} / \mathrm{a}$ & 1 & 14 \\
BETA $^{\mathrm{e}}$ & .7764 & .745 & .2971 & .1920 & 1.8060 \\
RISK-PREMIUM & .0504 & .0481 & .0241 & .0024 & .1373
\end{tabular}

C. Period 1984:1 to $1992: 12$

\begin{tabular}{llllll} 
Variables & Mean & Median & Std & Min & Max \\
\hline RISK-FREE $^{\mathrm{a}}$ & .1023 & .1013 & .0109 & .0819 & .1393 \\
BOND YIELD $^{\mathrm{b}}$ & .1122 & .1107 & .0107 & .0887 & .1511 \\
RATING $^{\mathrm{r}}$ & $\mathrm{n} / \mathrm{a}$ & $\mathrm{n} / \mathrm{a}$ & $\mathrm{n} / \mathrm{a}$ & 1 & 4 \\
INDUSTRY $^{\mathrm{d}}$ & $\mathrm{n} / \mathrm{a}$ & $\mathrm{n} / \mathrm{a}$ & $\mathrm{n} / \mathrm{a}$ & 1 & 14 \\
BETA $^{\mathrm{e}}$ & .9071 & .8840 & .3477 & .1150 & 3.0570 \\
RISK-PREMIUM & .0509 & .0493 & .0226 & .0068 & .1924 \\
\hline
\end{tabular}

Note: a'Long-term government of Canada bond yields. 'Scotia McLeod's AAA to BBB corporate bond yields. ${ }^{\mathrm{c} D B R S}$ bond rating. ${ }^{\mathrm{d}} \mathrm{TSE}$ industry classification. Transportation \& Environment industry is not represented in our sample because DBRS rated no companies in this industry. ${ }^{\mathrm{e}}$ Common stock beta from the TSE/Western data base. n/a not available.

The above model, however, does not identify years or months in which equity risk-premia are abnormal. As a result, an alternative model is used to test if risk-premia in a given year or month are different from the base year or month $j_{0}$. This model is

$$
R P_{i, t}=a_{0}+\sum_{j \neq j_{0}} a_{j} D_{i, t}^{j}+e_{i, t}
$$

where $j_{0}$ is the base year (1984) or month (January). 
TABLE 3. Regressions to Capture Variability in Equity Risk-Premia Across Months and Years

A. Regression Across Months

\begin{tabular}{|c|c|c|c|}
\hline Months & Coefficient $\left(a_{j}\right)$ & Months & Coefficient $\left(a_{j}\right)$ \\
\hline \multirow[t]{2}{*}{ January } & .051 & August & .054 \\
\hline & $(59.4)^{*}$ & & $(62.5)^{*}$ \\
\hline \multirow[t]{2}{*}{ February } & .051 & September & .051 \\
\hline & $(59.0)^{*}$ & & $(60.0)^{*}$ \\
\hline \multirow{2}{*}{ March } & .051 & October & .051 \\
\hline & $(59.4)^{*}$ & & $(60.0)^{*}$ \\
\hline \multirow[t]{2}{*}{ April } & .052 & November & .050 \\
\hline & $(60.5)^{*}$ & & $(58.3)^{*}$ \\
\hline \multirow[t]{2}{*}{ May } & .051 & December & .050 \\
\hline & $(59.3)^{*}$ & & $(58.6)^{*}$ \\
\hline \multirow[t]{2}{*}{ June } & .051 & & \\
\hline & $(59.6)^{*}$ & $\mathrm{R}^{2}$ & .01 \\
\hline July & $\begin{array}{r}.054 \\
(63.3)^{*}\end{array}$ & F-Statistic & $2.09 *$ \\
\hline
\end{tabular}

B. Regressions Across Years

\begin{tabular}{|c|c|c|c|}
\hline Years & Coefficient $\left(a_{\mathrm{j}}\right)$ & Years & Coefficient $\left(a_{\mathrm{j}}\right)$ \\
\hline \multirow[t]{2}{*}{1980} & .058 & 1987 & .051 \\
\hline & $(55.1)^{*}$ & & $(63.4)^{*}$ \\
\hline \multirow[t]{2}{*}{1981} & .063 & 1988 & .055 \\
\hline & $(60.9) *$ & & $(69.3)^{*}$ \\
\hline \multirow[t]{2}{*}{1982} & .042 & 1989 & .055 \\
\hline & $(40.7)^{*}$ & & $(72.4)^{*}$ \\
\hline \multirow[t]{2}{*}{1983} & .049 & 1990 & .053 \\
\hline & $(49.3)^{*}$ & & $(67.9)^{*}$ \\
\hline \multirow[t]{2}{*}{1984} & .040 & 1991 & .055 \\
\hline & $(42.2)^{*}$ & & $(68.2)^{*}$ \\
\hline \multirow[t]{2}{*}{1985} & .045 & 1992 & .054 \\
\hline & $(51.1)^{*}$ & & $(65.6)^{*}$ \\
\hline \multirow[t]{2}{*}{1986} & .046 & $\mathrm{R}^{2}$ & .05 \\
\hline & $(55.5)^{*}$ & F-Statistic & $45.74 *$ \\
\hline
\end{tabular}

Note: ${ }^{\text {aT }}$ The estimated model is $R P_{i, t}=\sum_{j} a_{j} D_{i, t}^{j}+e_{i, t}$, where $R P_{i, t}$ is the equity riskpremium for stock $i$ in year or month t, $D_{i, t}^{j}$ is a dummy variable that is equal to 1 if the current year or month is $\mathrm{j}$ and 0 otherwise, and $e_{i t}$ is the error term assumed to be normally distributed with zero mean and finite variance. $\mathrm{R}^{2, \mathrm{~s}}$ and F-statistics are obtained from model (2), which is: $a_{0}+\sum_{j \neq j_{0}} a_{j} D_{i, t}^{j}+e_{i, t}$ where $j_{0}$ is the base year (1984) or month (January). *Statistically significant at the $1 \%$ level. **Statistically significant at the $5 \%$ level. Parentheses include the t-values for the coefficients of dummy variables.

While the intercept indicates the average risk-premium in the base year or month, the rest of the coefficients reflect the difference of each of the remaining years or months from the base year or month. The F-statistic of this model is relevant and, hence, reported, and tests whether adding 
independent variables other than the base year or month to the model will reduce the variance, i.e., whether permitting different means helps explain the variance of the equity risk-premia.

The results from running the above models to test for variability in risk-premia across the year and over time are reported in table 3 . Model 1 in panel A of table 3 indicates that the average risk-premia per month differ from zero. Moreover, the differences between the mean riskpremia are so small from month to month that it is safe to assume these differences are not economic. This conclusion is reinforced from equation/model 2 results (not reported here), which show that only July and August differ statistically from January. The risk-premia for the rest of the months are not statistically different from January. This is also reinforced by the F-statistic, which is only marginally significant.

The evidence from table 3 , panel $\mathrm{B}$, however, is stronger and more conclusive. It shows that the equity risk-premia vary over time (FStatistic=45.74), suggesting that the market's perception of the higher risk of equity over debt changes. This is evident in the results of both models. All years' risk-premia are higher than the average riskpremium for 1984. These results are consistent with the findings of Harris and Marston (1992).

Finally, the evidence in table 3 , in conjunction with earlier evidence from table 2 (panels B and C), seems to indicate that while equity risk premia varied over time, average equity risk-premia remained relatively stable between the two sub-periods tested. This finding is quite interesting in light of the change in the CAPM market risk-premium between the two sub-periods, as discussed earlier and applied in the CAPM cost of equity estimation. The stability of the bond-plus riskpremium equity risk-premia may signify that the YTM incorporated in the bond-plus risk-premium model captures most of the structural changes experienced by the bond markets in the 1980s that prompted the change in the CAPM market risk premium (see also the discussion of the third contribution of the article in Section II.)

\section{Characteristics of Equity Risk-Premia}

This section examines the reason for the changes in equity risk-premia over time and tests to see whether (and how) the equity risk-premia vary cross-sectionally between stocks of different risk and industry classifications and at different points in the business cycle, as per our earlier discussion. 
Table 4 reports summary statistics for equity risk-premia for different rating classifications, industry classification, and points in the business cycle. The findings are as expected. The higher the bond rating, the lower the risk-premium (see panel A). Hence, we reject $\mathrm{H}_{0}{ }^{1}$. This finding is consistent with Harris (1986). Not only is there a similar inverse relationship between bond rating and risk-premia, but the difference between the risk-premia of the highest and lowest quality stocks is 103 basis points, exactly as high as the difference found by Harris (1986) in the U.S.

Panel B of table 4 shows that the lower the riskiness of an industry, the lower the equity risk-premium. As a result, we reject $\mathrm{H}_{0}{ }^{2}$. That is, Utilities and Pipelines, being regulated industries, tend to have the lowest equity risk-premia, while the Mines \& Minerals and Gold \& Precious Metals industries have the highest. Finally, the risk-premia are higher in recessions than recoveries, as shown in panel $\mathrm{C}$, although by not as much as one would have expected. Hence, $\mathrm{H}_{0}{ }^{3}$ is also rejected, but not as convincingly as $\mathrm{H}_{0}{ }^{1}$ or $\mathrm{H}_{0}{ }^{2}$.

Table 4 further quantifies this section's findings by running models (1) and (2) above to test the statistical significance of these findings. In model (1), $D_{i, t}^{j}$ is now defined as 1 if the current rating or industry or point in the business cycle is $j$ and 0 otherwise. In model (2), $j_{0}$ is the base rating (AAA) or industry (Metals \& Minerals) or point in the business cycle (recovery). While there are definite differences in the equity risk-premia between different ratings and industry classifications, there does not seem to be any statistical difference in risk-premia between recessions and recoveries.

Further evidence of the reasonableness of this study's estimated equity risk-premia could be provided by investigating the joint effects of our independent variables. Thus it would be helpful to subdivide the sample according to point in the business cycle and rating, rating and industry classification, point in the business cycle and industry classification, and point in the business cycle, rating and industry classification. However, while such data would afford us with a more refined and complete picture of how risk-premia are affected by combinations of the variables, limitations in data availability and sample size diminish the reliability of such findings. Nevertheless, some answer to the following questions would be of interest to analysts. Is it reasonable to add a constant risk-premium to all AAA companies? Does 
TABLE 4. Equity Risk-Premia by Bond Rarting, Industry Classifications, and Business Cycle Point

A. Risk-Premia of Equity Over Debt by Bond Rating

\begin{tabular}{lccc} 
& Median & Mean & T-values \\
\hline AAA & .040 & .044 & $(27.6)^{* a}$ \\
AA & .043 & .044 & $(0.00)$ \\
A & .051 & .053 & $(5.01)^{*}$ \\
BBB & .053 & .057 & $(7.22)^{*}$
\end{tabular}

$\mathrm{R}^{2}=0.03$

$\mathrm{F}-$ value $=106.42 *$

B. Risk-Premia of Equity by Industry Classification ${ }^{\mathrm{b}}$

\begin{tabular}{lccc} 
& Median & Mean & T-values \\
\hline Utilities & .020 & .027 & $(-19.9)^{*}$ \\
Pipelines & .034 & .034 & $(-39.9)^{*}$ \\
Merchandising & .042 & .045 & $(-32.2)^{*}$ \\
Financial Services & .043 & .045 & $(-19.4)^{*}$ \\
Consumer Products & .043 & .046 & $(-54.0)^{*}$ \\
Industrial Products & .054 & .056 & $(-42.7)^{*}$ \\
Oil \& Gas & .055 & .057 & $(-17.1)^{*}$ \\
Conglomerates & .057 & .060 & $(-30.3)^{*}$ \\
Communications \& Media & .060 & .057 & $(-37.4)^{*}$ \\
Paper \& Forest Products & .061 & .061 & $(-21.7)^{*}$ \\
Real Estate & .063 & .065 & $(-26.8)^{*}$ \\
Gold \& Precious Metals & .083 & .082 & $(-2.93)^{*}$ \\
Metals \& Minerals & .087 & .087 & $(95.2)^{* a}$ \\
$\mathrm{R}^{2}=0.3$ & & & \\
F-value=284.63* & & & \\
\hline
\end{tabular}

C. Risk-Premia of Equity Across the Business Cycle

\begin{tabular}{lccc} 
& Median & Mean & T-values \\
\hline Recoveries & .049 & .050 & $(202.1)^{* \mathrm{a}}$ \\
Recessions & .050 & .051 & $(0.01)$ \\
$\mathrm{R}^{2}=.00$ & & & \\
F-value $=.00$ & & & \\
\hline
\end{tabular}

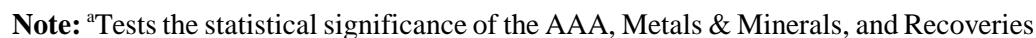
mean risk-premia, respectively. Rest of bracketed figures test whether remaining risk-premia are significantly different from the aforementioned mean risk-premia, as per model (2), described in table 3, where $\mathrm{R}^{2} \mathrm{~s}$ and $\mathrm{F}$-statistics have also been obtained. All mean risk-premia in this table are significantly different from zero at the $1 \%$ level of significance, as per model (1). ${ }^{\text {b}}$ Transportation \& Environment is not represented in our sample, as DBRS rated no companies in that industry. *Statistically significant at the $1 \%$ level. Parentheses include the t-values for the coefficients of dummy variables.

it not make any difference whether it is a recession or a recovery and whether a particular company is a Utility or a Gold Producer? 
TABLE 5. Equity Risk-Premia by Rating and Industry During Recovery and Recession for the Period 1980:1 to 1992:12a

A. Point in the Business Cycle - Recovery

\begin{tabular}{llll}
\multicolumn{3}{c}{ Industry } \\
\hline Utilities & Pipelines & Merchandising & Financial Services
\end{tabular}

\section{$\underline{\text { AAA }}$}

Median

Mean

.0190

Observations

.0240

49

$\mathrm{n} / \mathrm{a}$
$\mathrm{n} / \mathrm{a}$

$\mathrm{n} / \mathrm{a}$

.0320

$\underline{\mathbf{A A}}$

Median

Mean

Observations

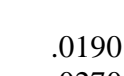

.0270

265

190

.0280

120

$\mathrm{n} / \mathrm{a}$

.0430

A

Median

.0210

.0280

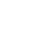

Observations

420

$365^{.0350}$

BBB

$\underline{\text { Median }}$

Mean

Observations

${ }_{95}^{.0220}$

.0470

.0440

23

$83^{.0380}$

66
.0500
.0490

717

$\begin{array}{ll}.0420 & .0360 \\ .0440 & 503 \\ & .0430\end{array}$

Industry

\begin{tabular}{lllll}
\cline { 2 - 3 } & Consumer & Industrial & Oil \& Gas & Conglomerates \\
\hline
\end{tabular}

\section{Median}

Mean

Observations

$\underline{\mathbf{A A}}$

Median

Mean

Observations

$\underline{\mathbf{A}}$

Median

Mean

Observations

BBB

Median

Mean

Observations

$0^{\mathrm{n} / \mathrm{a}}$

$\mathrm{n} / \mathrm{a}$
$\mathrm{n} / \mathrm{a}$

.0380
.0420

261

$533^{.0470}$

533

.0400
.0400

92

$\mathrm{n} / \mathrm{a}$
$\mathrm{n} / \mathrm{a}$

0

$\begin{array}{ll}\mathrm{n} / \mathrm{a} & .0440 \\ \mathrm{n} / \mathrm{a} & .0590\end{array}$

37

$\mathrm{n} / \mathrm{a}$

$\mathrm{n} / \mathrm{a}$

$\mathrm{n} / \mathrm{a}$
$\mathrm{n} / \mathrm{a}$
0

203

0

$193^{\circ}$

$702^{.0560}$

474.0570

.0670

.0680

203

$\begin{array}{rr}.0530 & .0490 \\ .0500 & 142.0490\end{array}$

(Continued) 
TABLE 5. (Continued)

\begin{tabular}{|c|c|c|c|c|c|}
\hline & \multicolumn{5}{|c|}{ Industry } \\
\hline & $\begin{array}{l}\text { Communications } \\
\& \text { Media }\end{array}$ & $\begin{array}{l}\text { Paper/ } \\
\text { Forest } \\
\text { Products }\end{array}$ & Real Estate & $\begin{array}{l}\text { Gold \& } \\
\text { Precious } \\
\text { Metals }\end{array}$ & $\begin{array}{l}\text { Metals \& } \\
\text { Minerals }\end{array}$ \\
\hline \multicolumn{6}{|l|}{$\underline{\mathbf{A A A}}$} \\
\hline$\overline{\text { Median }}$ & $\mathrm{n} / \mathrm{a}$ & $\mathrm{n} / \mathrm{a}$ & $\mathrm{n} / \mathrm{a}$ & $\mathrm{n} / \mathrm{a}$ & $\mathrm{n} / \mathrm{a}$ \\
\hline Mean & $\mathrm{n} / \mathrm{a}$ & $\mathrm{n} / \mathrm{a}$ & $\mathrm{n} / \mathrm{a}$ & $\mathrm{n} / \mathrm{a}$ & $\mathrm{n} / \mathrm{a}$ \\
\hline Observations & 0 & 0 & 0 & 0 & 0 \\
\hline \multicolumn{6}{|l|}{$\mathbf{A A}$} \\
\hline$\overline{\text { Median }}$ & .0720 & $\mathrm{n} / \mathrm{a}$ & .0600 & $\mathrm{n} / \mathrm{a}$ & $\mathrm{n} / \mathrm{a}$ \\
\hline Mean & .0670 & $\mathrm{n} / \mathrm{a}$ & .0610 & $\mathrm{n} / \mathrm{a}$ & $\mathrm{n} / \mathrm{a}$ \\
\hline Observations & 36 & 0 & 82 & 0 & 0 \\
\hline \multicolumn{6}{|l|}{$\underline{\mathbf{A}}$} \\
\hline $\bar{M}$ Median & .0550 & .0580 & .0720 & 0.088 & 0.076 \\
\hline Mean & .0500 & .0610 & .0680 & .0880 & 0.084 \\
\hline Observations & 140 & 343 & 227 & 118 & 206 \\
\hline \multicolumn{6}{|l|}{ BBB } \\
\hline$\overline{\text { Median }}$ & .0710 & 0.064 & .0610 & .0480 & .0890 \\
\hline Mean & .0740 & 0.060 & .0670 & .0420 & .0890 \\
\hline Observations & 23 & 234 & 141 & 10 & 196 \\
\hline
\end{tabular}

B. Point in the Business Cycle - Recession

\begin{tabular}{|c|c|c|c|}
\hline \multicolumn{4}{|c|}{ Industry } \\
\hline Utilities & Pipelines & Merchandising & Financial Services \\
\hline
\end{tabular}

\begin{tabular}{|c|c|c|c|c|}
\hline \multicolumn{5}{|l|}{$\underline{\mathbf{A A A}}$} \\
\hline Median & .0380 & $\mathrm{n} / \mathrm{a}$ & $\mathrm{n} / \mathrm{a}$ & .0390 \\
\hline Mean & .0370 & $\mathrm{n} / \mathrm{a}$ & $\mathrm{n} / \mathrm{a}$ & .0410 \\
\hline Observations & 23 & 0 & 0 & 54 \\
\hline \multicolumn{5}{|l|}{$\underline{\mathbf{A A}}$} \\
\hline Median & .0160 & $\mathrm{n} / \mathrm{a}$ & .0350 & .0430 \\
\hline Mean & .0150 & $\mathrm{n} / \mathrm{a}$ & .0360 & .0430 \\
\hline Observations & 62 & 0 & 13 & 171 \\
\hline \multicolumn{5}{|l|}{$\underline{\mathbf{A}}$} \\
\hline Median & .0300 & .0350 & .0420 & .0380 \\
\hline Mean & .0290 & .0370 & .0490 & .0420 \\
\hline Observations & 94 & 125 & 75 & 89 \\
\hline \multicolumn{5}{|l|}{$\underline{\text { BBB }}$} \\
\hline$\overline{\text { Median }}$ & .0210 & .0390 & .0580 & .0200 \\
\hline Mean & .0250 & .0390 & .0580 & .0200 \\
\hline Observations & 55 & 6 & 33 & 5 \\
\hline
\end{tabular}

(Continued) 
TABLE 5. (Continued)

\begin{tabular}{|c|c|c|c|c|c|}
\hline & \multicolumn{5}{|c|}{ Industry } \\
\hline & Consumer & Industrial & Oil \& C & Con & glomerates \\
\hline \multicolumn{6}{|l|}{$\underline{\mathbf{A A A}}$} \\
\hline$\overline{\text { Median }}$ & $\mathrm{n} / \mathrm{a}$ & $\mathrm{n} / \mathrm{a}$ & \multicolumn{2}{|c|}{.0840} & $\mathrm{n} / \mathrm{a}$ \\
\hline Mean & $\mathrm{n} / \mathrm{a}$ & $\mathrm{n} / \mathrm{a}$ & \multicolumn{2}{|c|}{.0830} & $\mathrm{n} / \mathrm{a}$ \\
\hline Observations & 0 & 0 & \multicolumn{2}{|c|}{11} & 0 \\
\hline \multicolumn{6}{|l|}{$\underline{\mathbf{A A}}$} \\
\hline$\overline{M e d i a n}$ & .0550 & .0510 & \multicolumn{2}{|c|}{.0570} & $\mathrm{n} / \mathrm{a}$ \\
\hline Mean & .0560 & .0500 & \multicolumn{2}{|c|}{.0540} & $\mathrm{n} / \mathrm{a}$ \\
\hline Observations & 48 & 36 & \multicolumn{2}{|c|}{61} & 0 \\
\hline \multicolumn{6}{|l|}{$\underline{\mathbf{A}}$} \\
\hline $\bar{M}$ edian & .0420 & .0570 & \multicolumn{2}{|c|}{.0600} & .0620 \\
\hline Mean & .0460 & .0550 & \multicolumn{2}{|c|}{.0690} & .0620 \\
\hline Observations & 173 & 176 & \multicolumn{2}{|c|}{121} & 49 \\
\hline \multicolumn{6}{|l|}{$\underline{\mathbf{B B B}}$} \\
\hline Median & .0430 & .0540 & \multicolumn{2}{|c|}{.0660} & .0490 \\
\hline Mean & .0440 & .0560 & \multicolumn{2}{|c|}{.0620} & .0490 \\
\hline \multirow[t]{3}{*}{ Observations } & 28 & 124 & 46 & & 26 \\
\hline & \multicolumn{5}{|c|}{ Industry } \\
\hline & $\begin{array}{l}\text { Communications } \\
\& \text { Media }\end{array}$ & $\begin{array}{l}\text { Paper/ } \\
\text { Forest } \\
\text { Products }\end{array}$ & Real Estate & $\begin{array}{l}\text { Gold \& } \\
\text { Precious } \\
\text { Metals }\end{array}$ & $\begin{array}{l}\text { Metals \& } \\
\text { Minerals }\end{array}$ \\
\hline \multicolumn{6}{|l|}{$\underline{\mathbf{A A A}}$} \\
\hline$\overline{\text { Median }}$ & $\mathrm{n} / \mathrm{a}$ & $\mathrm{n} / \mathrm{a}$ & $\mathrm{n} / \mathrm{a}$ & $\mathrm{n} / \mathrm{a}$ & $\mathrm{n} / \mathrm{a}$ \\
\hline Mean & $\mathrm{n} / \mathrm{a}$ & $\mathrm{n} / \mathrm{a}$ & $\mathrm{n} / \mathrm{a}$ & $\mathrm{n} / \mathrm{a}$ & $\mathrm{n} / \mathrm{a}$ \\
\hline Observations & 0 & 0 & 0 & 0 & 0 \\
\hline \multicolumn{6}{|l|}{$\underline{\mathbf{A A}}$} \\
\hline$\overline{\text { Median }}$ & .0700 & $\mathrm{n} / \mathrm{a}$ & .0720 & $\mathrm{n} / \mathrm{a}$ & $\mathrm{n} / \mathrm{a}$ \\
\hline Mean & .0640 & $\mathrm{n} / \mathrm{a}$ & .0690 & $\mathrm{n} / \mathrm{a}$ & $\mathrm{n} / \mathrm{a}$ \\
\hline Observations & 24 & 0 & 26 & 0 & 0 \\
\hline \multicolumn{6}{|l|}{$\underline{\mathbf{A}}$} \\
\hline $\bar{M}$ edian & .0600 & .0710 & .0480 & .0680 & .0920 \\
\hline Mean & .0560 & .0710 & .0530 & .0690 & .0900 \\
\hline Observations & 28 & 71 & 49 & 26 & 70 \\
\hline \multicolumn{6}{|l|}{ BBB } \\
\hline$\overline{\text { Median }}$ & .0710 & .0600 & .0460 & $\mathrm{n} / \mathrm{a}$ & .0860 \\
\hline Mean & .0710 & .0600 & .0470 & $\mathrm{n} / \mathrm{a}$ & .0870 \\
\hline Observations & 13 & 86 & 13 & 0 & 56 \\
\hline
\end{tabular}

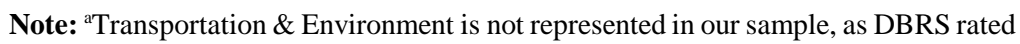
no companies in that industry. n/a: not available. 
TABLE 6. Pooled Data Regressions of Equity Risk-Premia

\begin{tabular}{|c|c|c|c|c|}
\hline \multirow[b]{2}{*}{ Variables } & \multicolumn{4}{|c|}{ Regression Equations } \\
\hline & (1) & (2) & (3) & (4) \\
\hline Intercept & .0600 & .0510 & .0594 & .0594 \\
\hline Risk- free ${ }^{b}$ & $\begin{array}{c}(44.2)^{*} \\
-.0860 \\
(7.04)^{*}\end{array}$ & $(29.1)^{*}$ & $(27.5)^{*}$ & $(13.2)^{*}$ \\
\hline Business cycle ${ }^{c}$ & & $\begin{array}{l}-.0010 \\
(2.85)^{*}\end{array}$ & & \\
\hline Yield $^{\mathrm{d}}$ & & & $\begin{array}{c}-.0732 \\
(6.86)^{*}\end{array}$ & \\
\hline Spread $^{\mathrm{e}}$ & & & & $\begin{array}{l}-.9596 \\
(41.1)^{*}\end{array}$ \\
\hline $\mathrm{R}^{2}$ & .01 & .01 & .01 & .13 \\
\hline Durbin-Watson & 2.00 & 2.00 & 2.00 & 2.00 \\
\hline
\end{tabular}

Note: ${ }^{\text {TThe }}$-statistics shown in this table are the result of re-estimating the regressions using the maximum likelihood method, as the original regressions' Durbin-Watson statistics indicated a high degree of positive autocorrelation in the regression errors. Coefficients do not change materially when multiple regressions are run combining the variables in the table. ${ }^{b}$ Long-term government of Canada bond yields. ${ }^{\mathrm{c}} 1$ if recession, 0 otherwise. ${ }^{\mathrm{d}}$ Average Scotia

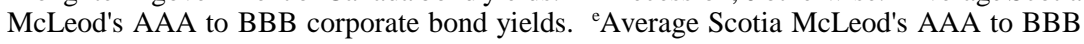
corporate bond yields less the government of Canada bond yields. *Statistically significant at the $1 \%$ level. $* *$ Statistically significant at the $5 \%$ level. $* * *$ Statistically significant at the $10 \%$ level. Parenthesis include the t-values for the coefficients of dummy variables.

Table 5 attempts to answer the above questions by reporting average equity risk-premia for the combination of point in the business cycle, bond rating, and industry classification. The data availability and sample size limitations are apparent. For example, almost half of the AAA bond rating data are from the early 1980 s period (i.e., recession years) when risk-premia were higher than average and most industries, with the exception of Utilities, Financial Services, and Oil \& Gas, had no debt rated in this class. ${ }^{12}$ The most reliable equity risk-premia in this table are those for the A bond rating class, as (i) it is the class with the most observations, (ii) all industries had bonds rated in this class and (iii) data were consistently available for the whole sample period.

Finally, to provide tests of the stability of the relationship between equity risk-premia and interest rates/business cycle, we also run a number of pooled time-series/cross-sectional OLS regressions with the equity risk-premia as the dependent variable for our total sample.

12. As Jaffe (1975) notes, bond rating agencies do not adjust their ratings for short-term business cycle developments. 
TABLE 7. Pooled Data Regressions of Equity Risk-Premia Different Periods

A. Period 1980:1 to $1983: 12$

Regression Equations

\begin{tabular}{|c|c|c|c|c|}
\hline Variables $^{\mathrm{a}}$ & (1) & (2) & (3) & (4) \\
\hline \multirow[t]{2}{*}{ Intercept } & .0590 & .0480 & .0660 & 0.0630 \\
\hline & $(15.5)^{*}$ & $(14.7)^{*}$ & $(15.4)^{*}$ & $(17.9)^{*}$ \\
\hline \multirow[t]{2}{*}{ Risk-free } & -.0690 & & & \\
\hline & $(2.44)^{*}$ & & & \\
\hline \multirow[t]{2}{*}{ Business Cycle } & & .0030 & & \\
\hline & & $(5.97)^{*}$ & & \\
\hline \multirow[t]{2}{*}{ Yield } & & & -.1070 & \\
\hline & & & $(5.40)^{*}$ & \\
\hline \multirow[t]{2}{*}{ Spread } & & & & -1.1190 \\
\hline & & & & $(26.8)^{*}$ \\
\hline $\mathrm{R}^{2}$ & .02 & .02 & .01 & 0.23 \\
\hline Durbin-Watson & 2.00 & 2.00 & 2.00 & 1.99 \\
\hline
\end{tabular}

B. Period 1984:1 to $1992: 12$

Regression Equations

\begin{tabular}{|c|c|c|c|c|}
\hline \multirow[b]{2}{*}{ Variables $^{\mathrm{a}}$} & \\
\hline & (1) & (2) & (3) & (4) \\
\hline \multirow[t]{2}{*}{ Intercept } & .0740 & .0510 & .0780 & 0.0570 \\
\hline & $(32.1)^{*}$ & $(27.5)^{*}$ & $(31.1)^{*}$ & $(29.2)^{*}$ \\
\hline \multirow[t]{2}{*}{ Risk-free } & -.2330 & & & \\
\hline & $(10.3)^{*}$ & & & \\
\hline \multirow[t]{2}{*}{ Business Cycle } & & -.0020 & & \\
\hline & & $(4.78)^{*}$ & & \\
\hline \multirow[t]{2}{*}{ Yield } & & & -.2490 & \\
\hline & & & $(16.2)^{*}$ & \\
\hline \multirow[t]{2}{*}{ Spread } & & & & -0.7040 \\
\hline & & & & $(-20.6)^{*}$ \\
\hline $\mathrm{R}^{2}$ & .01 & .01 & .03 & 0.04 \\
\hline Durbin-Watson & 2.00 & 2.00 & 2.00 & 1.99 \\
\hline
\end{tabular}

Note: ${ }^{\mathrm{a}}$ For definitions of the independent variables, see notes in table 6 . *Statistically significant at the $1 \%$ level. **Statistically significant at the $5 \%$ level. ***Statistically significant at the $10 \%$ level. Parenthesis include the t-values for the coefficients of dummy variables. 
(1980:1 to $1992: 12$ ) and two sub-periods (1980:1 to $1983: 12$, and 1984:1 to 1992:12). The total period breakdown has been chosen in this fashion in order to split the period into two sub-periods to capture the change in U.S. monetary policy after 1984 . The U.S. Fed reverted to a more traditional mixture of the federal funds rate and monetary aggregates as targets (Jaffee [1989, p. 499]), and Canada and the Canadian capital markets directly mirrored the impact of this change. We expect to find a negative relationship between equity risk-premia and interest rates. The intuition for this expectation is furnished by Fama and Schwert (1977), among others. It is based on the fact that high interest rates imply high inflation. Since bonds are not a good hedge against unexpected inflation, bond return requirements should increase relative to equity return requirements at high rates and the equity risk-premium should decrease.

In all original regressions, the Durbin-Watson statistic was significantly lower than 2 (typically less than one), indicating a high degree of positive autocorrelation in the residuals. Thus the abovestated regressions had to be re-estimated using the maximum likelihood method (Judge et al. [1985, Chapter 8]) which provides consistent and efficient estimates for regression parameters and for testing the hypotheses on these parameters. The results from these re-estimated regressions, reported in tables 6 and 7, show a negative relationship between risk-premia and interest rates (both the long-term government of Canada bond yields $\left(R_{f}\right)$ and corporate $Y T M \mathrm{~s}$ ) and yield spreads (the difference between $Y T M$ and $R_{f}$ ), in a way consistent with our expectations and previous studies (Gordon and Halpern [1976], Brigham et al. [1985], Harris [1986], Shome and Smith [1988], Harris and Marston [1992]). ${ }^{13}$

From all variables tested, the only unstable relationship is that between risk-premia and the business cycle. In fact, the reason that in our earlier tests we did not find a significant economic difference in risk-premia between recessions and recoveries is that while there was, as expected, a positive relationship between the business cycle and riskpremia in the 1980-1983 sub-period, the relationship reversed in the 1984-1992 sub-period. This unexpected negative relationship may have been caused by the fact that risk-premia had started to rise well before the officially declared period of recession in early 1990. The period

13. Multiple regressions were also run, but the simple regression coefficients of individual variables did not materially change. 
around and after the October 1987 crash of stock markets was a period of heightened uncertainty and increased difficulties of companies overburdened with the high debt levels assumed in the 1980s.

\section{Implications and Conclusions}

This article proposes an alternative approach to estimating the cost of equity capital. The approach is consistent with the CAPM and can be used in conjunction with or instead of the CAPM. It is more easily understood and applied by practitioners, and is especially useful in cases where CAPM's application is cumbersome (i.e., when a beta estimate is not reliable or available).

Using the bond-plus risk-premium approach, we estimate individual stock equity risk-premia. These risk-premia are then classified into bond-rating groups based on DBRS bond ratings and industry groups based on TSE industry classifications. Averages are calculated per group. We find the equity risk-premia to be negatively related to bond rating and positively related to the risk of an industry group. These findings are stable, consistent with our expectations, and robust across years and sub-periods. The same is true for the relationship between equity risk-premia and interest rates.

However, our findings concerning the equity risk premia's sensitivity to the business cycle and stability across business cycles are not very conclusive. There are many other factors that can simultaneously work to affect risk-premia at various points in the business cycle, making the results too unreliable for solid recommendations to be given. Hence, such comparisons should be avoided.

We find, with the exception of the 1981 risk-premia, the average risk-premia for the years of our study vary between $4.5 \%$ and $5.5 \%$. A practitioner can use the model and findings of this article in the following way. First, he/she can obtain an estimate of the YTM of the company's bonds, if they trade. If they do not, then the average YTM for bonds of the same rating class should be obtained from DBRS and used as a proxy of the company's long-term debt YTM. Second, the equity risk-premium for point in the business cycle/company rating/industry classification should be obtained from tables 4 and/or 5 
and added to step one's YTM. The summation of these two terms will be an estimate of the company's cost of equity capital. This approach will be particularly useful for estimating the cost of equity of entities for which beta estimates are not available, such as privately-held companies and divisions of multi-business companies.

\section{References}

Booth, L. 1985. On shaky ground. Canadian Investment Review (Spring) 8: 9-15.

Boyle, P. P.; Panjer, H. H.; and Sharp, K. P. 1989. Report on Canadian economics statistics, 1924-1988. Ottawa: Canadian Institute of Actuaries.

Boyle, P. P.; Panjer, H. H.; and Sharp, K. P. 1984. Report on Canadian Economics Statistics, 1924-1983. Ottawa: Canadian Institute of Actuaries.

Brealey, R. A., and Myers, S. C. 1988. Principles of Corporate Finance, Third Edition. McGraw-Hill Book Company.

Brealey, R. A.; Myers, S. C.; Sick, G.; and Giammarino, R. 1992. Principles of Corporate Finance, Second Canadian Edition. McGraw-Hill.

Brealey, R. A.; Myers, S. C.; Sick, G.; and Whaley, R. 1986. Principles of Corporate Finance, First Canadian Edition. McGraw-Hill.

Brigham, E.; Shome, D.; and Vinson, S. 1985. The risk premium approach to measuring a utility's cost of equity. Financial Management (Spring) 14: $33-45$.

Chan, L. K. C.; Hamao, Y.; and Lakonishok, J. 1991. Fundamentals and stock returns in Japan. Journal of Finance 46(5):1739-1764.

Cornell, B.; Hirshleifer, J. I.; and James, E. P. 1997. Estimating the cost of equity capital. Contemporary Finance Digest 1(Autumn):5-26.

Fama, E. F., and French, K. R. 1992. The cross-section of expected stock returns. Journal of Finance 47(2):427-465.

Fama, E. F., and French, K. R. 1989. Business conditions and expected returns on stocks and bonds. Journal of Financial Economics 25:23-49.

Fama, E. F., and Schwert, G. W. 1977. Asset returns and inflation. Journal of Financial Economics 5:115-146.

Fowler, D.; Rorke, C. H.; and Jog, V. M. 1980. Thin trading and beta estimation problems on the Toronto Stock Exchange. Journal of Business Administration (Fall):77-90.

Gordon, M. J., and Halpern, P. 1976. Bond share yields spreads under inflation. American Economic Review (September):559-565. 
Harris, R. S. 1986. Using analysts' growth forecasts to estimate shareholder required rates of return. Financial Management 15 (Spring): 58-67.

Harris, R. S., and Marston, F. S. 1992. Estimating shareholder risk premia using analysts'growth forecasts. Financial Management 21 (Summer): 6370.

Hatch, J. E., and White, R. W. 1988. Canadian Stocks, Bonds, Bills and Inflation: 1950-1987. Charlottesville, Virginia: The Research Foundation of the Institute of Chartered Financial Analysts.

He, J., and Ng, L. K. 1992. Economic forces, fundamental variables, and equity returns. CBA Working Paper Series - 248, University of Houston.

Ibbotson Associates, Inc. 1990. Stocks, Bonds, Bills and Inflation, 1990 Yearbook, Chicago, IL.

Jaffee, D. M. 1989. Money, Banking and Credit. Worth Publishers, Inc.

Jaffee, D. M. 1975. Cyclical variations in the risk structure of interest rates. Journal of Monetary Economics 1:309-325.

Judge, G.; Griffiths, W. E.; Hill, R. C.; Lutkephol, H.; and Lee, T. C. 1985. The Theory and Practice of Econometrics, 2nd Edition. John Wiley.

Lakonishok, J., and Shapiro, A. 1986. Systematic risk, total risk and size as determinants of stock market returns. Journal of Banking and Finance 10: 115-132.

Maddox, F. M.; Pippert, D. T.; and Sullivan, R. N. 1985. An empirical study of ex-ante risk premiums for the electrical utility industry. Financial Management 14 (Autumn): 89-95.

Malkiel, B. 1979. The capital formation problem in the United States. Journal of Finance 34 (May):291-306.

Pettengill, G. N.; Sundaram, S.; and Mathur, I. 1995. The conditional relation between beta and returns. Journal of Financial and Quantitative Analysis 30 (March): 101-116.

Reilly, F. K., and Drzycimski, E. 1974. Alternative industry performance and risk. Journal of Financial and Quantitative Analysis 9 (June): 423-446.

Shome, D. K., and Smith, S. D. 1988. An econometric analysis of equity costs and risk premiums in the electric utility industry: 1971-1985. Financial Management 17 (November): 439-452.

Vandell, R. F., and Kester, G. W. 1983. A History of Risk Premia Estimates for Equities: 1944-1978. Charlottesville, Virginia: Financial Analysts Research Foundation.

Wakerman, L. M. 1990. The real function of bond rating agencies. In C. W. Smith, Jr. (ed), The Modern Theory of Corporate Finance.

Weston, J. F., and Copeland, T. E. 1992. Managerial Finance, Ninth Edition. Dryden Press. 